\title{
Effect of Oreodoxa oleracea Jacq. pollen protein allergen in albino mice
}

\author{
Dimphna Nneka Ezikanyi ${ }^{1}$, Happiness Oselebe ${ }^{2}$
}

1Palynology Unit, Department of Applied Biology, Faculty of Science, Ebonyi State University, Abakaliki, Nigeria ${ }^{2}$ Department of Crop Science, Faculty of Agriculture, Ebonyi State University, Abakaliki, Nigeria

Adv Dermatol Allergol 2020; XXXVII (4): 566-571

DOI: https://doi.org/10.5114/ada.2020.98286

\begin{abstract}
Introduction: Pollen trigger allergenic reactions in hypersensitive individuals due to the presence of protein in their sporoderm.

Aim: Pollen protein produced by Oreodoxa oleracea was subjected to allergenicity test in mice in order to determine its allergenic potential.

Material and methods: Pollen protein was extracted using $0.02 \mathrm{M}$ phosphate buffered saline and used to inoculate mice by two subcutaneous and one intranasal injections weekly for 4 weeks. Blood samples were obtained by retroorbital bleedings, sera obtained were used in detecting immunoglobulin E (IgE) by immunoperoxidase assay. Values of immune cell and IgE elicited in mice were analysed using SPSS statistical package version 20.

Results: Oreodoxa oleracea yielded $208 \mu \mathrm{g} / \mathrm{ml}$ pollen protein allergen. Inoculation of pollen protein in mice produced dermatophytic allergic reactions which physically presented as swelling, rashes and hair loss. Pollen protein skewed basophil production and infiltration of lymphocytes by $1-62 \%$ and $58-99 \%$ respectively in relation to controls. Histopathology analysis showed inflammation within the lung parenchyma.

Conclusions: The present study is the first study to evaluate the allergenic potential of Oreodoxa oleracea in mice. The findings revealed that Oreodoxa oleracea which is profoundly planted in pubic areas for aesthetic purposes possess allergenic effect.
\end{abstract}

Key words: Oreodoxa oleracea, pollen protein, allergy, immune cell, mice.

\section{Introduction}

When pollen are dispersed from plants, they are released into ambient air, although their mission is to fertilise the flowers of the same species, sometimes they make unscheduled detours into human noses, skin and throats. At these sites, pollen trigger allergic reactions, which is referred to as pollinosis, which many people know as hay fever or rose fever [1]. Pollen, which have the aerodynamic size of $15-40 \mu \mathrm{m}$, probably cannot enter the lower thoracic regions of the respiratory tract; instead, they affect the nasal or nasopharyngeal mucous membrane [2, 3] whereas the smaller ones within 5-14 $\mu \mathrm{m}$ are easily filtered by the lower airways [4] where the allergens are leaked out on hydration [5].

Pollen allergens belong to type one hypersensitivities, their proteins are immunomodulatory substances, which play crucial roles in the sensitization and/or exacerbation of allergies such as seasonal rhinitis, conjunctivitis, asth- ma, bronchial constriction and obstruction, pollinosis and atopic dermatitis etc. [6] In a response to an allergen, the immune system produces immunoglobulin E antibodies which attach to immune cells, these undergo degranulation and trigger the cells to release histamine and other inflammatory chemical mediators. These chemical mediators elicit symptoms of allergy including wheezing, runny nose, itching, rashes, sneezing etc. These symptoms range from mild to life-threatening symptoms and could either be localized or systemic [7].

Between $10 \%$ and $25 \%$ of the population experience symptoms of hay fever or allergic asthma due to a pollen allergen and the incidence has increased over the past two decades, the reason(s) for this increment are only hypothetical. In Europe, the prevalence of allergic rhinitis was found to be around 25\% [8]. The prevalence of confirmable allergic rhinitis in adults in Europe ranged from $17 \%$ (Italy) to $28.5 \%$ (Belgium) [9]. The incidence and prevalence of allergic rhinitis has increased worldwide over the

Address for correspondence: Dimphna Nneka Ezikanyi, Palynology Unit, Department of Applied Biology, Faculty of Biological Sciences, Ebonyi State University, Abakaliki, Ebonyi, Nigeria, e-mail: dimphna.nneka@yahoo.com Received: 22.01.2019, accepted: 4.02.2019. 
past 10 years affecting $39.2 \%$ of school children aged 13 to 14 years in Nigeria $[8,10]$. The prevalence of allergic asthma varies depending on the geographical location. Asthma is a common respiratory disease in Nigeria with up to 15 million people suffering from the disease (NTS, 2016). Pollen is one of the major environmental factors which exacerbate and induce respiratory allergies, especially asthma [11]. Results of the prevalence of 'nasal allergy' have been published in few studies. Gourango et al. showed that application of mango protein to mice produced a change in the physical appearance and a rise in the levels of eosinophils and neutrophils by $2-5.5 \%$ and $34-77.5 \%$ respectively, relative to the normal levels. In Japan, Japanese cedar (C. japonica) pollen is a major spring aeroallergen [12] and elicits pathogenic symptoms including rhinitis and/ or conjunctival congestion accompanied by pollen-specific IgE production [1]. Pollen allergies are more difficult to diagnose and treat than other allergies because they are far more numerous and antigenically variable than other allergies and are exceedingly difficult to avoid. Assessment of pollen allergenicity has become paramount in understanding the allergenic plants in our environment, this is also important in effective diagnosis and management of pollen related allergens [13].

Oreodoxa oleracea is an ornamental palm plant, which belongs to the Arecaceae family. It has become increasingly used as an indoor and outdoor plant in households, large hotels and airport terminal buildings to enhance floral aesthetics.

\section{Aim}

The aim of the present study is to evaluate the allergenic potential of Oreodoxa oleracea in mice. No previous research was carried out on Oreodoxa oleraceae allergenicity.

\section{Material and methods}

\section{Sample collection}

Bunches of mature Oreodoxa oleracea flowers with yellow colour were collected from Yaba College of Technology environs, Yaba, Lagos, Nigeria. The anthers were carefully detached from the inflorescence and dried at room temperature for 3 days indoors in plastic trays.

All chemicals and reagents used in the study were of analytical grades and procured from Asophos chemicals, Ojuelegba, Lagos, Nigeria. Immunoglobulin E (IgE) kit GWB 626057 used for the measurement of the antibodies was procured from GenWay Laboratory Technologies, United States of America.

\section{Extraction of pollen protein}

Anthers were defatted with $50 \mathrm{ml}$ of diethyl ether three times. They were homogenized with mortar and pestle in $100 \mathrm{ml}$ of $0.02 \mathrm{M}$ phosphate buffered saline (PBS) at $\mathrm{pH}$ 7.4. The mixtures were stirred overnight at $4^{\circ} \mathrm{C}$, filtered with a muslin cloth, centrifuged and supernatant retained. The protein precipitation was carried out using $50 \mathrm{~g}$ of ammonium sulphate and dialysed against PBS overnight. Protein concentration was assayed according to Bradford procedures. The extract was concentrated by freeze-drying and the pollen proteins were stored at $-80^{\circ} \mathrm{C}$ for later use in inoculating into experimental animals (mice).

\section{Inoculation of the pollen protein extract}

Male albino mice which were 4-6 weeks old were purchased from the Nigerian Institute of Medical Research, maintained under a 12-hour light-dark cycle with free access to water and standard laboratory food. All experimental procedures conformed to international standards of animal welfare and an ethical approval was obtained from the Nigerian Institute of Medical Research. Protein extracts were reconstituted with distilled water, mice were inoculated with $100 \mathrm{mg} / \mathrm{kg}$ of the pollen protein by two subcutaneous and one intranasal injections weekly for 4 weeks, control mice received an equivalent volume of phosphate buffered saline. Blood samples were obtained by retro-orbital bleeding using heparinized capillary tubes and both pre and post sera obtained were stored at $-80^{\circ} \mathrm{C}$ for later use in detecting immunoglobulin levels. Thin blood smears were also obtained from the tail vein, fixed with methanol and flooded with Leishman's stain for 7-10 min and washed in a stream of buffered water. Quantification of immune cells was based on a count of hundred immune cells per slide.

\section{Immuno assay for determination \\ of immunoglobulin $E$ in mice sera}

Elisa IgE kit GWB 626057 purchased from GenWay Laboratory Technologies, United States of America, was employed for the immunoassay. All manufacturer's instructions on reagent dilution with distilled water were strictly adhered to and prepared prior to use. Test samples $(100 \mu \mathrm{l})$ were measured into predesignated microtitre wells and incubated for $30 \mathrm{~min}$. After removal of unbound protein by washing with Elisa machine, the wells were blotted to remove residual buffer. Anti-lgE antibodies conjugated with horseradish peroxidase (HRP) were added and incubated for $30 \mathrm{~min}$, this was followed by another washing. The enzyme bound to the immunosorbent was assayed by the use of chromogenic substrate, 3,3',5,5'-tetramethylbenzidine (TMB). Absorbance at $450 \mathrm{~nm}$ was determined which was a measure of the concentration of immunoglobulin $\mathrm{E}$ in the test sample. The values of immunoglobulin $E$ in the test samples were interpolated from the standard curve constructed from the standards and corrected for sample dilution. 


\section{Histological examination}

Animals were sacrificed after the $4^{\text {th }}$ week by cervical dislocation and dissected. The respiratory organs were obtained and processing of tissue samples for histological assessment followed established procedures of Kuo (2007) [14]. The data obtained were analysed using the SPSS statistical package version 20 (SPSS Inc. Chicago, Illinois, USA). Descriptive and frequency statistics were generated to examine the means of immune cells and immunoglobulin E.

\section{Results and discussion}

\section{Protein concentration and effect in mice}

Bradford protein assay revealed a protein content of $208.11 \mu \mathrm{g} / \mathrm{ml}$ in Oreodoxa oleracea pollen. The pollen protein elicited allergenic extrinsic inflammatory reaction which physically presented as swelling, rashes and hair loss on the skin compared to control mice (Figure 1). Intrinsic inflammation within the lung parenchyma was also elicited (Figure 2). This agrees with Shalaby et al. who observed that allergenic proteins possess inherent properties or are associated with danger signals that target receptors, mediating allergic inflammatory responses [15]. Shahali et al. however revealed noticeable differences in protein content of two varieties of Cupressus arizonica; C. arizonica var. arizonica and C. arizonica var. glabra planted in Tehran; their work showed that there are some intraspecies specificities in their pollen protein content which may be influenced by environmental conditions [16].

\section{Pollen-specific immunoglobulin E (IgE) in mice sera}

Mice sensitized with the Oreodoxa oleracea pollen protein showed an increase in immunoglobulin E, relative to the control mice (Figure 3), hence its pollen protein shows allergenicity in mice. Immunoglobulin E has long been known as the landmark of allergy. Babu et al. [17] also showed that immunoglobulin plays a key role in allergic reactions, particularly in the early phase response. Therefore, measurement of allergen-specific immunoglobulin $\mathrm{E}$ is indicated for evaluating pollen allergy. There was observable allergen sensitivity on the skin and respiratory route which were the two sites of inoculation. This finding is consistent with a study by Edimyor et al. [18], which shows that allergen exposure through the nasal and respiratory mucosa induces a strong rise of allergen-specific immunoglobulin E levels, which are responsible for increased allergen sensitivity in the target organs of allergy. Many studies have investigated the use of specific immunoglobulin E antibodies as a diagnostic tool in allergic diseases [19]. However, studies have indi-
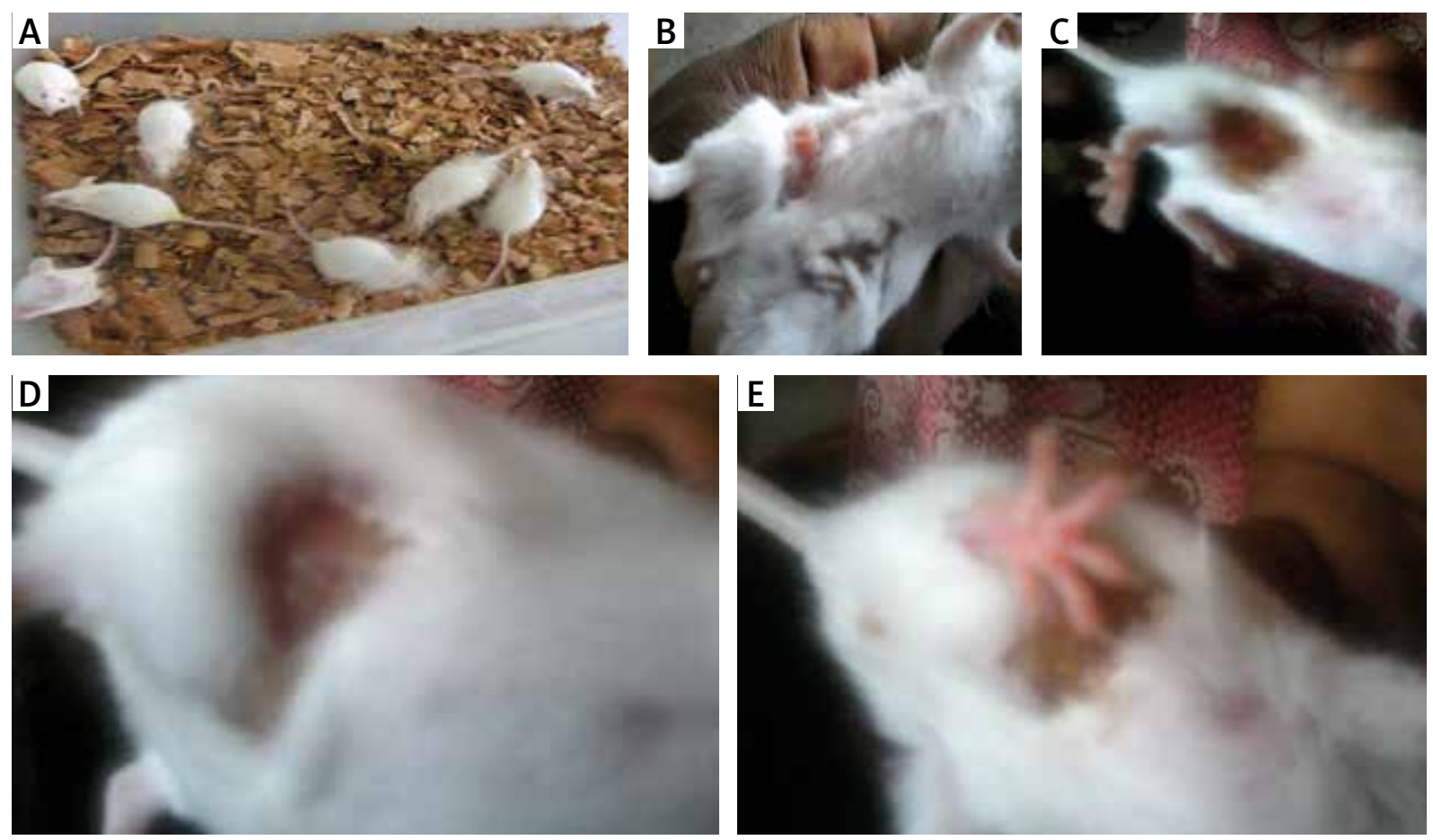

Figure 1. Physical features of allergy: A - control mice showing no physical feature of allergy, B - mice inoculated with Oreodoxa oleracea showed a feature of allergy, which physically presented as swelling, C, D - mice inoculated with Oreodoxa oleracea showed a sign of allergy, which presented as hair loss, E - mice inoculated with Oreodoxa oleracea showed a sign of allergy, which presented as rashes 

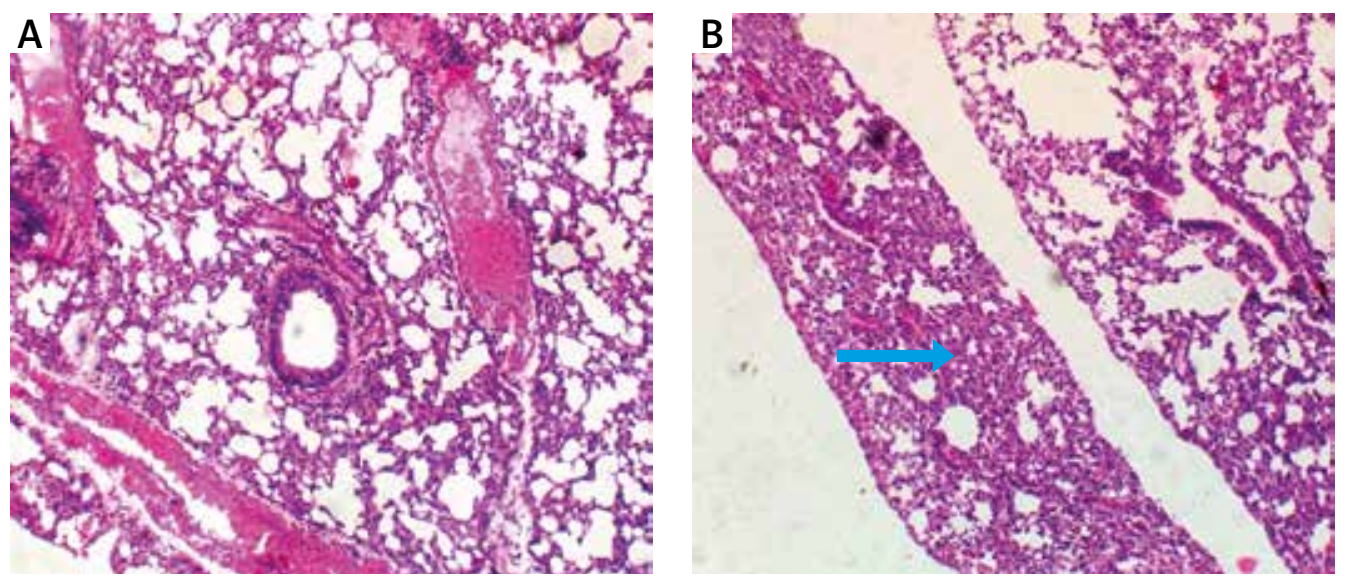

Figure 2. Lungs of mice: A - lung of control mice, B - lung of mice inoculated with Oreodoxa oleracea. Mag. 1000x. Blue arrow shows inflammation within the lung parenchyma

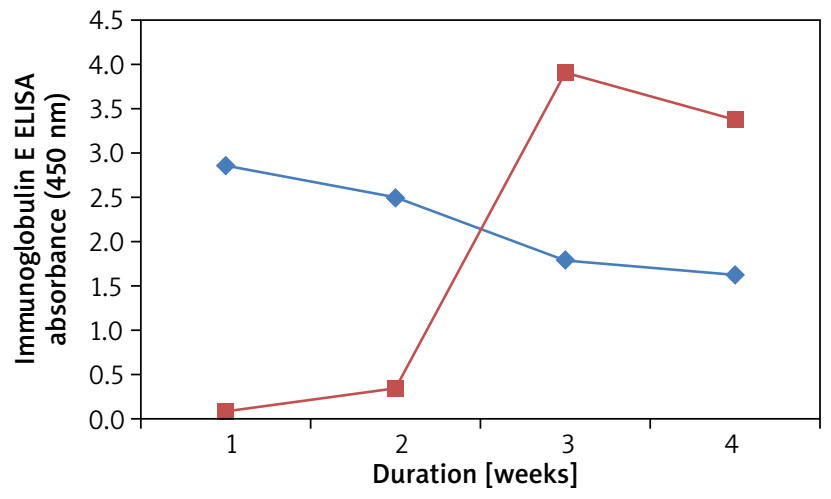

- Mice sensitized with Oreodoxa oleracea pollen protein - Control mice

Figure 3. Immunoglobulin E elicited by Oreodoxa oleracea in mice

cated that total immunoglobulin E (IgE) value could be influenced by many factors such as gender, age and race $[20,21]$.

\section{Immune cells present in mice}

Among the immune cells only lymphocytes and basophils were abundantly produced in response to Oreodoxa oleracea pollen protein allergen.

Lymphocytes were $87 \%$ at week one before sensitization, they decreased after the second sensitization to $58 \%$ and increased to $99 \%$ after the third sensitization, on a count of less than twenty fields, indicating infiltration unlike in control mice. In control mice which received phosphate buffered saline, lymphocytes dominated other leucocytes from week 1 to week 4 , but on a count of more than fifty fields. Total lymphocytes elicited by Oreodoxa oleracea were not significantly different from the controls $(p<0.05)$ (Figure 3). The infiltration of lymphocytes in

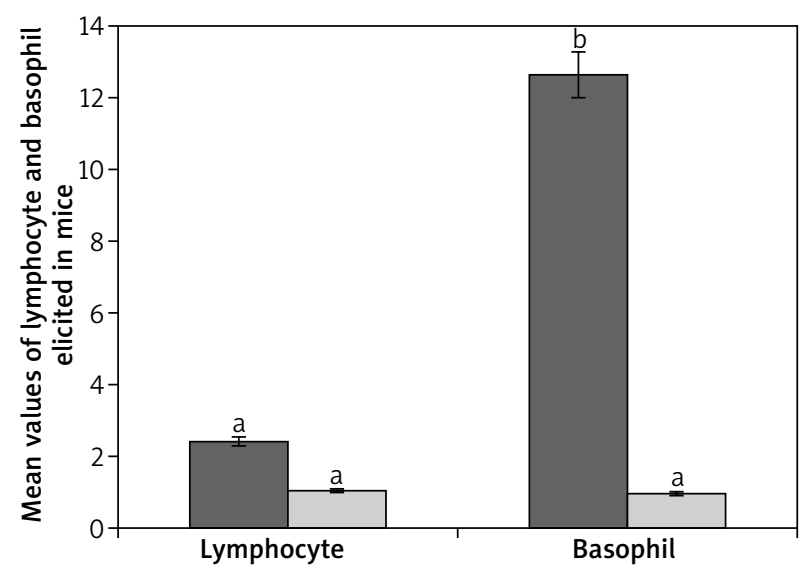

$\square$ Mice sensitized with Oreodoxa oleracea pollen protein $\square$ Control mice

Figure 4. Mean values of lymphocytes and basophils elicited by pollen protein and PBS in sensitized and control mice respectively. Mean bars with different alphabet letters $(a, b)$ are significantly different $(p<0.05)$. Lymphocyte and basophil are expressed by mean values divided by the number of microscope fields

sensitized mice correlated with an increase in IgE in mice, indicating a profound role that lymphocytes play in immunity and allergy [22].

Oreodoxa oleracea pollen protein allergen skewed basophil production at week 2 of inoculation (62\%), it became lowered at week 3 (1\%). Total basophils elicited by Oreodoxa oleracea were significantly different from the controls $(p<0.05)$ (Figure 4). The infiltration of basophils could be responsible for both extrinsic (dermatophytic reactions) and intrinsic (inflammation within the lung parenchyma) properties. Gibbs [23] noted that despite their relatively low numbers compared with other effec- 
tor cells, such as mast cells and eosinophils, they have long been suspected as a major player in initiating and maintaining allergic inflammation and disorders [24].

The clinical features of inflammation within the lung parenchyma may contribute to the development of airflow limitation by increasing airway resistance, which is a typical feature of asthma. Adrian et al. [25] showed that asthma is characterized by thickening of the airway wall and by the presence of the inflammatory process, though different among various kinds. The allergic inflammation induced by Oreodoxa oleracea could trigger not only bronchial but also lung parenchyma remodelling and these histological changes are associated with concurrent changes in respiratory mechanics of the animal.

\section{Mortality rate}

A high mortality rate was observed in mice inoculated with Oreodoxa oleracea pollen protein after the third sensitization and was not observed in control mice. The present study shows that pollen released from Oreodoxa oleracea are allergenic and could trigger allergies in hypersensitive individuals, its allergenicity was found to possess both extrinsic and intrinsic properties in mice, there is further need for its allergenicity studies in higher organisms, to fully elucidate its mechanisms especially as it is recently a priority for aesthetic purposes.

\section{Acknowledgments}

The pilot study of this research was carried out in University of Lagos but was fully studied during my postdoctoral fellowship in the Muhimbili University of Health and Allied Sciences, Tanzania, a program sponsored by the Association of Commonwealth Universities (ACU) in collaboration with the African Academy of Sciences (AAS) on CIRCLE (Climate Impact Research Capacity and Leadership Enhancement Programme). Authors grateful to the sponsors of the program and also very thankful to the staff of the Department of Environmental and Occupational Health, Tanzania for their hospitality, friendliness and collegiality. We appreciate Ebonyi State University, Abakaliki for a one-year relief from duties to undertake postdoctoral fellowship.

\section{Conflict of interest}

The authors declare no conflict of interest.

\section{References}

1. Gourango T, Ismile H, Nitai R, et al. Allergen protein from mango (Mangifera indica) flowers pollen. AsPac J Mol Biol Biotechnol 2012; 20: 11-8.

2. Hoehne $\mathrm{JH}$, Reed CE. Where is the allergic reaction in ragweed asthma? J Allergy Clin Immunol 1971; 48: 36-9.
3. Wilson AF, Novey HS, Berke RA, Surprenant EL Deposition of inhaled pollen and pollen extract in human airways. N Engl J Med 1973; 228: 1056-8.

4. Sarkary Z, Kudela G, Horvath A, et al. Evaluation of the effect of lung morphometry on the deposition of inhaled particles. Acta Med Marisiensis 2012; 58: 446-50.

5. Grote M, Vrtala S, Niederberger V, et al. Expulsion of allergen containing materials from hydrated rye grass (Lolium perenne) pollen revealed by using immunogold field emission scanning and transmission electron microscopy. J Allergy Clin Immunol 2000; 105: 1140-5.

6. Kamijo S, Takai T, Kuhara T, et al. Cupressaceae pollen grains modulate dentritic cell response and exhibit IgE inducing adjuvant activity in vivo. J Immunol 2013; 183: 6087-94.

7. Singh $A B$, Kumar P. Aerial pollen diversity in India and their clinical significance in allergic diseases. Indian J Clin Biochem 2004; 19: 190-201.

8. Bauchau V, Durham SR. Prevalence and rate of diagnosis of allergic rhinitis in Europe. Eur Respir J 2004; 24: 758-64.

9. Tunis MD, Murant MD. The burden of allergic rhinitis and asthma. Ther Adv Respir Diseases 2012; 6: 11-3.

10. Basak P, Arayata R, Brensilver J. Prevalence of specific aeroallergen sensitivity on skin prick test in patients with allergic rhinitis in Westchester County. Internet J Asthma Allergy Immunol 2008; 6: 2-10.

11. Dick S, Doust E, Cowie H. Association between environmental exposures and asthma control and exacerbations in young children: a systematic review. BMJ Open 2014; 4: 003827.

12. Sakaguchi M, Kobayashi C, Inouye S, et al. The incidence of Japanese cedar pollinosis and sensitization to the pollen allergens among Japanese monkeys in a troop. Immunology 2013; 97: 522-5.

13. D’ Amato GD, Cecchi L, Bonini S, et al. Allergenic pollen and pollen allergy in Europe. Allergy 2007; 1111: 1398-413.

14. Kuo J. Processing of plant tissue for ultrastructural study. J Mol Biol 1996; 36: 35-45.

15. Shalaby KH, Allard-Coutu A, Sullivan MJ, et al. Inhaled birch pollen extract induces airway hyperresponsiveness via oxidative tress but independently of pollen-intrinsic NADPH oxidase activity, or the TLR4-TRIF pathway. J Immunol 2013; 191: 922-33.

16. Shahali Y, Majd A, Pourpak Z, et al. Comparative study of the pollen protein contents in two major varieties of $\mathrm{Cu}$ pressus arizonica planted in Tehran. Iran J Allergy Asthma Immunol 2007; 6: 123-7.

17. Babu KS, Ashad SH, Aolgate ST. Immunology. Allergy 2001; 56: 1121-8.

18. Edimayor J, Niespodziana K, Linhart B, et al. A combination vaccine for allergy and Rhinovirus infections based on Rhinovirus-derived surface protein VP1 and a non allergenic peptide of the major timothy grass pollen allergen Ph 1 P1. J Immunol 2009; 182: 6298-306.

19. Khadadah ME, Onadeko BO, Ezemuzie Cl, et al. Studies on the relationship between allergen-specific IgE antibodies and skin test reactivity in patients with asthma in Kuwait. Med Princ Pract 2000; 9: 260-7.

20. Arinola OG. Serum total IgE levels in healthy children and adults in Ibadan, Nigeria. Tanzan Med J 2008; 23: 9-10.

21. Ogunlade OA, Ige OM, Arinola OG, Onadeko BO. Allergenspecific immunoglobulin E (IgE) antibodies and skin test reactivity in patients with asthma in Nigeria. J Clin Immunol Immunopathol Res 2012; 4: 25-8. 
22. Toda M, Sato H, Takebe Y, et al. Inhibitor of immunoglobulin E response to Japanese cedar pollen allergen (Cry J 1) in mice by DNA immunization; different outcomes dependent on the plasmid DNA inoculation method. Immunology 2000; 9: 179-86.

23. Gibbs BF. Basophils as key regulators of allergic inflammation and Th2 type immunity. WAO J 2008; 1: 123-8.

24. Martin LB, Kita H, Leiferman KM, Gleich GJ. Eosinophil in allergy: role in disease degranulation and cytokines. Int Arch Allergy Immunol 1996; 109: 207-15.

25. Adrian S, Chad W, Chandrika C, Mario C. Mechanism of remodeling in asthmatic airways. J Allergy 2012; 2012: 316049. 